\title{
30. MINERAL CHEMISTRY OF BASALTS FROM HOLES 483 AND 483B ${ }^{1}$
}

\author{
S. E. Barker, A. M. Kudo, and K. Keil, Department of Geology and Institute of Meteoritics, \\ University of New Mexico, Albuquerque, New Mexico
}

\section{INTRODUCTION}

During DSDP Leg 65, a series of holes was drilled into the oceanic basement across the mouth of the Gulf of California to study the composition of the crust and the nature of its construction at a young spreading center. In Holes 483 and 483B, two of the deepest basement holes drilled on this leg, the basement is characterized by an upper sequence of interlayered massive basalts and sediments underlain by a lower sequence of interlayered pillow and massive basalts. Electron microprobe analyses were performed on pyroxene, plagioclase, olivine, spinel, and glass from 14 representative samples of 10 of the 16 major lithologic units (Table 1). These analyses along with petrographic results can be used to interpret the detailed crystallization history of the basalts. We believe from the results of this study that the basalts were formed by at least a three-stage cooling process, followed by eruption and formation of quench phases. Our data do not support magma mixing.

\section{ANALYTICAL PROCEDURES}

Analyses were made with an ARL-EMX-SM electron microprobe operated at an accelerating voltage of $15 \mathrm{KeV}$ with corrections for differential matrix effects, according to Bence and Albee (1968). All mineral analyses were done with a sample current of 0.020 to 0.025 $\mu \mathrm{A}$. The glass analyses were done with a $6-10 \mu \mathrm{m}$ beam, a 10 -s counting period, and a sample current of $0.015 \mu \mathrm{A}$.

\section{PETROGRAPHY}

Low temperature alteration is common throughout Holes 483 and 483B. Olivine and interstitial glass are commonly replaced by smectite and minor carbonate. Veins and vesicles are generally filled with carbonate or smectite and less commonly with zeolite. In most samples, olivine phenocrysts and groundmass olivine have been completely altered to smectite. Microprobe analyses were made frequently on relict cores found in the center of altered olivine grains. Pyroxene and plagioclase are relatively fresh and unaltered.

Textures vary considerably within any given unit, changing from spherulitic to variolitic to intersertal in the chilled margins through intergranular to subophitic in the interior of the flows. Although rare, large, euhedral olivine phenocrysts occur in some samples. The dominant liquidus phase appears to be plagioclase. The range of crystal morphologies is dependent on the cooling rate and the nature of the liquidus phases (Bryan,

\footnotetext{
${ }^{1}$ Lewis, B. T. R., Robinson, P., et al., DSDP Init. Repts., 65: Washington (U.S. Govt. Printing Office).
}

Table 1. Samples studied and their lithologic unit.

\begin{tabular}{lcll}
\hline $\begin{array}{c}\text { Sample } \\
\text { (Depth in cm) }\end{array}$ & $\begin{array}{c}\text { Lithologic } \\
\text { Unit No. }\end{array}$ & $\begin{array}{c}\text { Type of } \\
\text { Cooling Unit }\end{array}$ & $\begin{array}{l}\text { Phenocryst } \\
\text { Assemblage }\end{array}$ \\
\hline 483-13-4, 64 & 1 & Massive basalt & Pl-Ol \\
483-17-2, 78 & 4 & Massive basalt & Aphyric \\
483-20-1, 49 & 6 & Pillow basalt & Pl-Ol-Cpx \\
483-22-1, 2 & 6 & Pillow basalt & Pl-Ol-Cpx \\
483-23-1, 132 & 6 & Massive basalt & Pl-Ol \\
483-26-3, 146 & 7 & Massive basalt & Aphyric \\
483B-2-7, 91 & 1 & Massive basalt & Pl-Ol \\
483B-13-3, 129 & 5 & Pillow basalt & Pl-Ol-Cpx \\
483B-19-1, 109 & 6 & Massive basalt & Aphyric \\
483B-22-1, 51 & 7 & Pillow basalt & Pl-Ol-Cpx \\
483B-25-2, 93 & 8 & Massive basalt & Pl-Ol-Cpx \\
483B-28-1, 78 & 8 & Massive basalt & Pl-Ol (Aphyric) \\
483B-30-1, 140 & 9 & Pillow basalt & Pl-Ol-Cpx \\
483B-32-2, 141 & 9 & Pillow basalt & Pl-Ol \\
\hline
\end{tabular}

1972; Natland, 1979). Plagioclase shows the greatest range of crystal morphologies. The larger single phenocrysts are commonly euhedral, although fragmented pieces do occur, but plagioclase crystals in glomeroporphyritic aggregates range from euhedral to subhedral and are joined in a synneusis relationship (Vance, 1969) (Plate 1). The large, equant phenocrysts appear to have rounded cores commonly filled with inclusions of glass. Euhedral, lath-shaped, skeletal, and acicular textures are most common in the microphenocrysts and groundmass. "Bow tie" intergrowths of plagioclase with pyroxene (Plate 1) and olivine occur in the glass of many samples. Large, euhedral olivine grains usually occur unaggregated. The single most striking feature of the pyroxene phenocrysts is the hourglass sector zoning with superimposed oscillatory zoning.

\section{APHYRIC BASALTS}

All our samples of aphyric basalts are from massive basalt units. The rare plagioclase phenocrysts that occur in Samples 483-26-3, $146 \mathrm{~cm}$ and 483B-19-1, $109 \mathrm{~cm}$ have cores more calcic $\left(\mathrm{An}_{83-76}\right)$ than the groundmass, but the rim compositions $\left(\mathrm{An}_{67-40}\right)$ are similar. These phenocrysts are anhedral with some embayment and melt inclusions.

Groundmass and microphenocryst compositions in another aphyric basalt, Sample 483-17-2, $78 \mathrm{~cm}$, are usually high, ranging up to $\mathrm{An}_{85}$; in contrast, a solitary glomerocryst in the same sample, which is over ten times the size of the groundmass grains, ranges in An-content from 84.5 to 79 . Perhaps this magma is more primitive or of a hybrid origin. 


\section{PHYRIC BASALTS}

The phyric basalts sampled in Holes 483 and 483B have three recognizable phenocryst assemblages: (1) plagioclase, (2) plagioclase + olivine, and (3) plagioclase + olivine + pyroxene. These phenocrysts show a large diversity of crystal morphologies, glomerocrysts, intergrowths, and zoning patterns (especially in plagioclase). The cooling histories for these basalts appear to involve at least three stages, based on the difference in shape and composition between plagioclase in Assemblage 1 and those in Assemblages 2 and 3. The plagioclase crystals in Assemblage 1 are more equant, and their range of compositions is on the average $\mathrm{An}_{92-85}$. The same phenocrysts and microphenocrysts in Assemblages 2 and 3 are more tabular and have average compositions less than $\mathrm{An}_{83}$.

\section{Olivine}

Olivine phenocrysts $(2.0-0.5 \mathrm{~mm})$ and microphenocrysts are typically euhedral to subhedral. In some cases there are anhedral grains which suggest resorption at some stage of crystallization. Uncommon inclusions of plagioclase $\left(<\mathrm{An}_{85}\right)$ in phenocrysts occur, indicating that plagioclase was the liquidus phase before olivine. Microphenocrysts of olivine, intergrown with elongated plagioclase laths, are present in some phyric rocks which have crystallized at a faster cooling rate and which also have plagioclase and pyroxene on the liquidus. This texture is similar to the "bow tie" glomerocrysts seen with pyroxene and plagioclase.

Figure 1 presents the results for olivine analyses in four porphyritic basalts and one aphyric basalt. Olivine data are scarce because of extensive smectite alteration throughout the samples. The range of phenocryst composition is $\mathrm{Fo}_{86.7}$ to $\mathrm{Fo}_{79.1}$ and for the groundmass is $\mathrm{Fo}_{82.9}$ to $\mathrm{Fo}_{75.3}$. Samples 483-23-1, $132 \mathrm{~cm}$ and 483B-13-3, $129 \mathrm{~cm}$ show very strong iron enrichment between phenocrysts and groundmass. None of these phenocrysts has a high magnesium content $\left(\mathrm{Fo}_{91-88}\right)$ or disequilibrium features, which suggests that they might have come from a

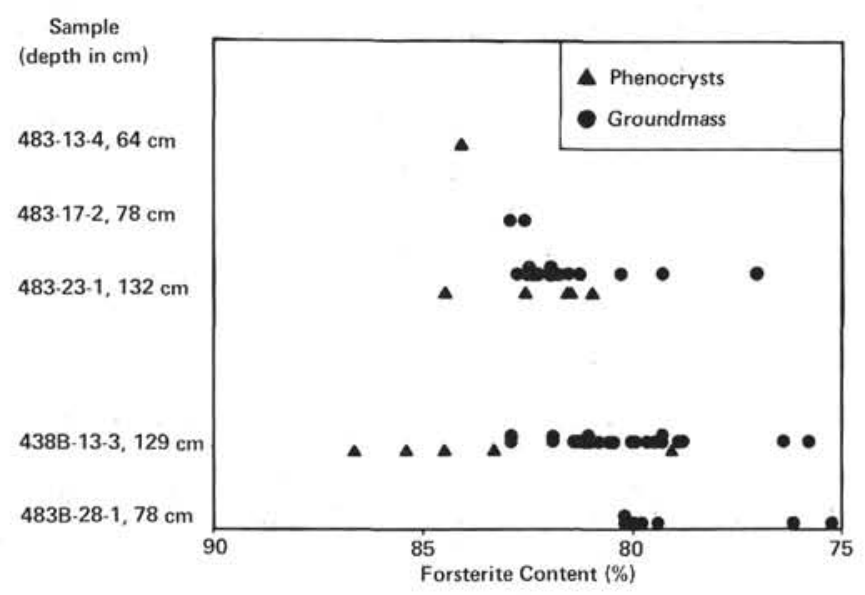

Figure 1. Olivine phenocryst and groundmass forsterite content, Holes 483 and 483B. more primitive magma (Donaldson and Brown, 1977; Blanchard et al., 1976). Moreover, undetectable Ni values $(<0.1 \mathrm{wt} . \%)$ suggest that these phenocrysts are not xenocrysts since olivine in peridotites of mantle origin gives consistent $\mathrm{Ni}$ values of about 0.40 wt. \% (Sato, 1977).

\section{Clinopyroxene}

Clinopyroxene phenocrysts range in size from $<1$ $\mathrm{mm}$ to $2 \mathrm{~mm}$ and are generally smaller than associated olivine and plagioclase phenocrysts. Clinopyroxene and plagioclase laths are almost always found in glomeroporphyritic aggregates or intergrown as "bow tie" glomerocrysts (Thompson et al., 1976). This feature is interpreted as a product of cotectic growth starting from a common nucleus (Bryan et al., 1976). Most of the clinopyroxene grains are euhedral, except for those forming more complex intergrowths. Clinopyroxene grains exhibit irregular extinction and complex zoning patterns in some samples. Sector zoning and concentric oscillatory zoning are well developed in Sample 483B-22-1, $51 \mathrm{~cm}$ (Plate 1). Studies made on sector-zoned pyroxenes in lunar basalts have attributed their formation to rapid growth in a supercooled magma (Hollister and Hargraves, 1970; Hollister et al., 1971, 1972). Because sectorzoned phenocrysts in our samples occur only in the more quenched margins of flows, it is reasonable to conclude that they are a product of rapid growth under fast cooling conditions. This suggests that clinopyroxene is not a liquidus phase before eruption.

Figures 2 and 3 present quadrilateral plots of clinopyroxene phenocrysts and groundmass clinopyroxene for the 14 aphyric and phyric basalts sampled. Groundmass clinopyroxene shows very strong iron enrichment and weaker calcium depletion. This strong iron enrichment trend in the groundmass is typical of ocean-floor basalts (Bunch and LaBorde, 1976; Bence et al., 1976) and is considered a result of rapid metastable crystallization linked to undercooling (Kirkpatrick, 1976). Minor amounts of subcalcic augite and magnesian to intermediate pigeonite occur in the late stage groundmass.

The chromium content in the cores of the clinopyroxene phenocrysts is, on average, less than $0.6 \mathrm{wt} . \%$ and in the groundmass it is usually less than $0.10 \mathrm{wt} . \%$. Chromium zoning in these phenocrysts fluctuates a great deal with no apparent consistency. This inconsistency can be best explained by the metastable growth of these phenocrysts in a rapidly cooled environment as indicated by sector zoning.

\section{Plagioclase}

Plagioclase is the most abundant phenocryst in the basalts in Holes 483 and 483B. The phenocrysts range in size from large equant grains (up to $4 \mathrm{~mm}$ in diameter) to lath-shaped microphenocrysts. The plagioclase crystals exhibit many complex morphological variations, resulting from the different cooling rates under which they grew. Very rapid cooling rates promote a high nucleation density and formation of small skeletal to acicular shapes (Lofgren, 1974). In many cases, the nucleation of tabular to acicular plagioclase crystals ap- 

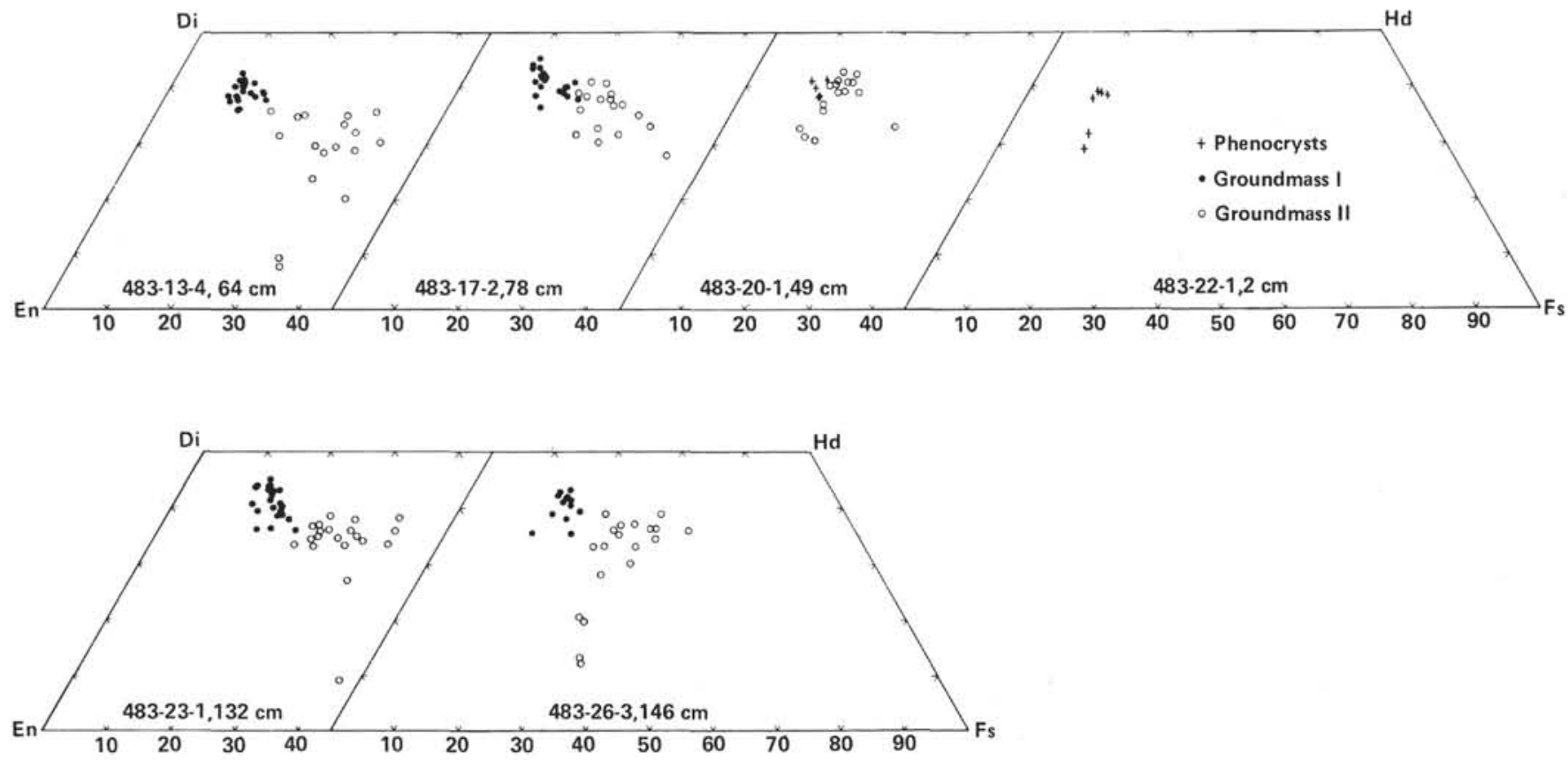

Figure 2. Pyroxenes from Hole 483. Groundmass I represents core compositions of granular to subophitic pyroxenes, and groundmass II represents rim compositions of grains in contact with or enclosed by melt.
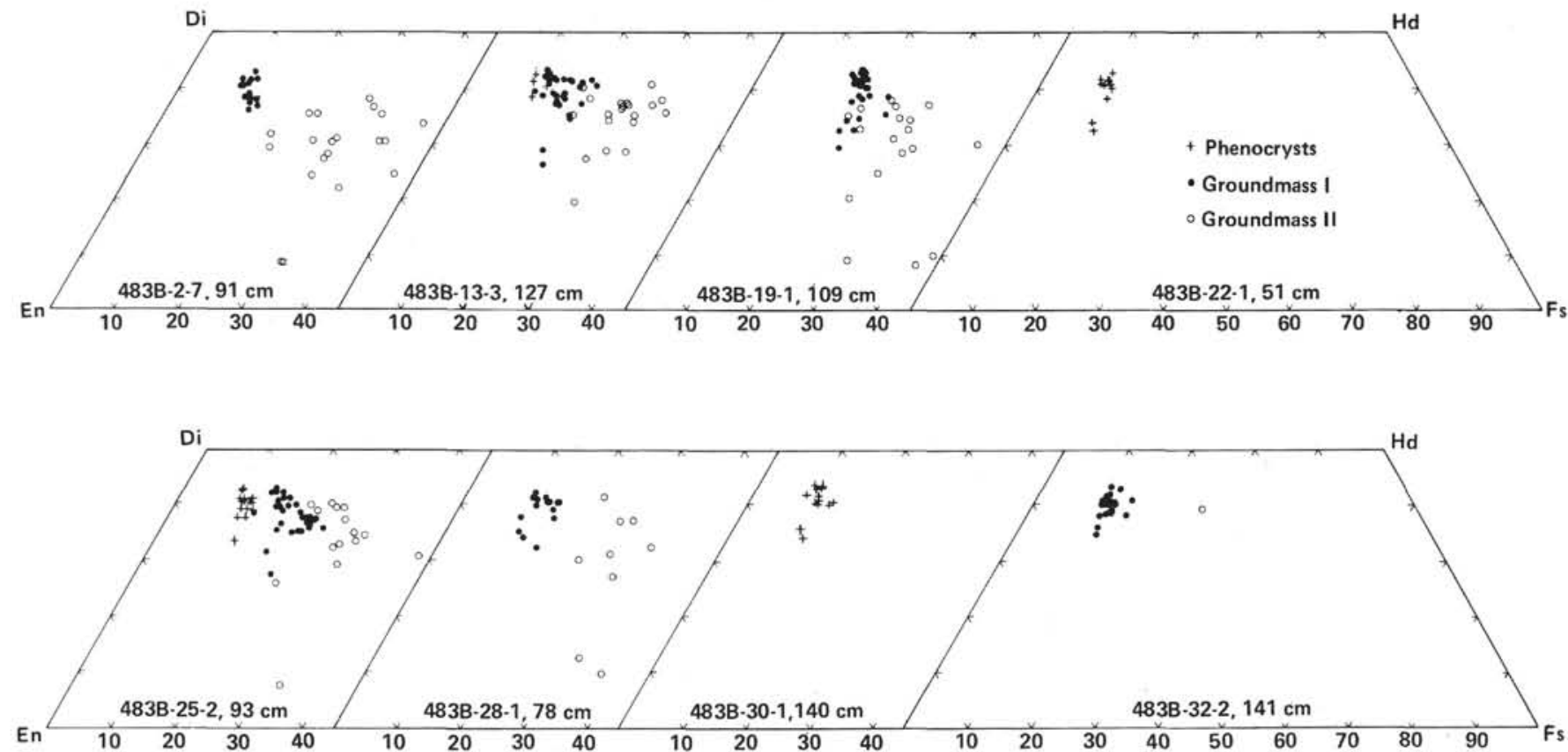

Figure 3. Pyroxenes from Hole 483B. Groundmass I represents core compositions of granular to subophitic pyroxenes, and groundmass II represents rim compositions of grains in contact with or enclosed by melt.

pears to have occurred around small broken fragments of larger phenocrysts. Slower cooling rates have a much larger effect on the width of a grain than the length, thus causing more equant shapes (Bryan, 1972; Coish and Taylor, 1979) (Fig. 4). Recently, Lofgren and Smith (1980) have stressed the importance of nucleation density in addition to cooling rate on the ultimate size and shape of crystals. Several distinct types of compositional zoning occur in the plagioclase crystals, including normal, reversed, unzoned, and oscillatory zoning. In a few phenocrysts, sector zoning is present (Plate 1). These patterns suggest that crystallization took place in a variety of equilibrium and disequilibrium conditions.

Inclusions of glass are common in the cores and rims of many phenocrysts as well as in many of the cores of groundmass plagioclase crystals (Plate 1). In some of the larger phenocrysts, the plagioclase surrounding the glass inclusions displays convolute zoning (Blackerby, 

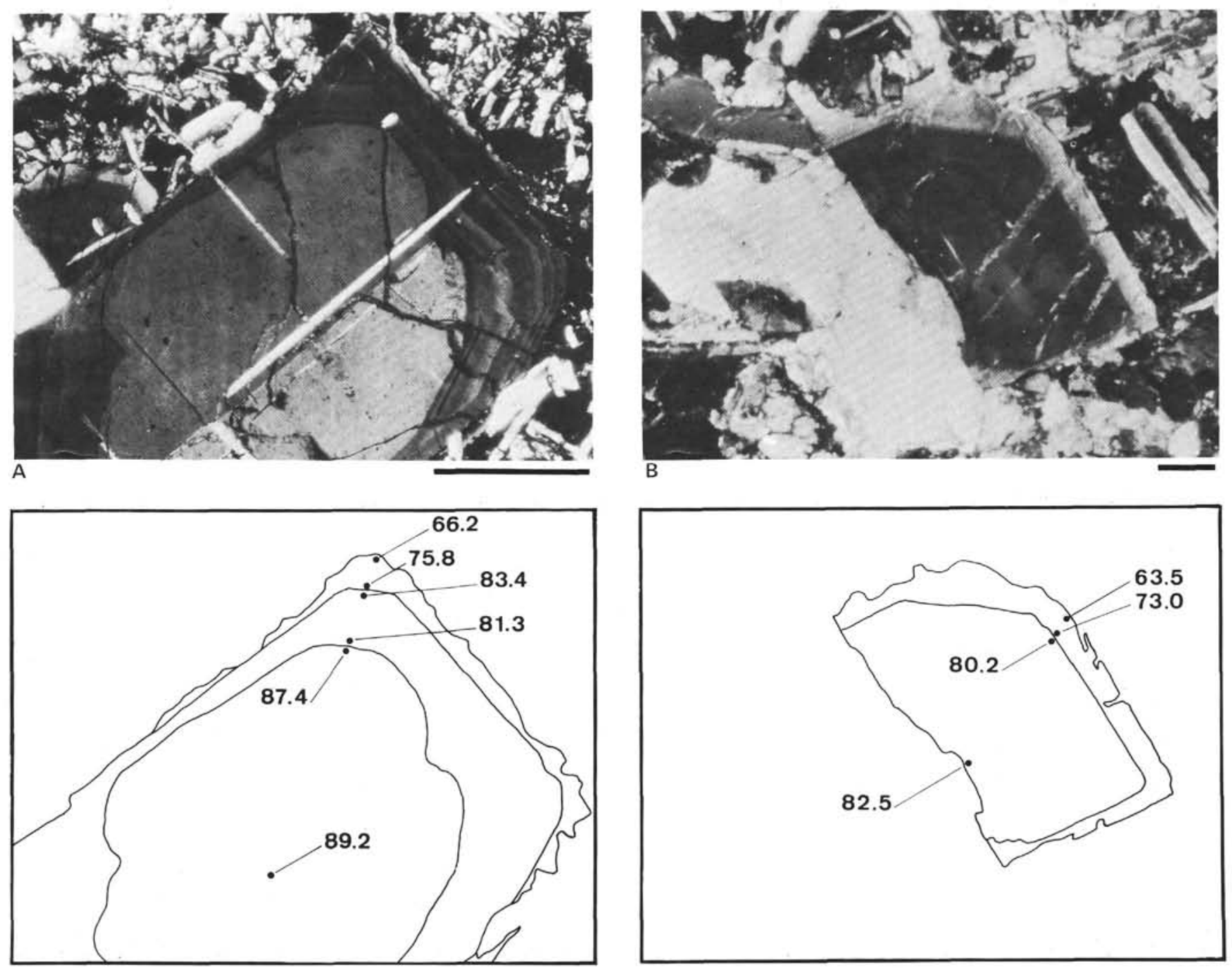

Figure 4. Plagioclases with overgrowth rims having compositional discontinuities. A. Plagioclase phenocryst from Sample 483B-2-7, $91 \mathrm{~cm}$. (Scale bar equals $0.5 \mathrm{~mm}$.) B. Second generation microphenocryst from Sample 483B-2-7, $91 \mathrm{~cm}$. (Scale bar equals $0.1 \mathrm{~mm}$.)

1968 ) in which the zones are compressed and bent near the glass (Fig. 5). Blackerby (1968) interpreted this texture as a product of primary growth rather than corrosion. In his experimental study of zoning in synthetically grown plagioclase, Lofgren (1973) observed trapped melt inclusions which resemble resorption textures but are primary growth features. Since the melt inclusions become more albitic as crystallization proceeds, crystallization and growth are impeded and the melt inclusions are preserved. Hence, glass inclusions in the plagioclase are formed by entrapment of melt by the growing plagioclase during cooling rather than by resorption. This process explains the presence of glass inclusions in groundmass plagioclase which was obviously formed during quenching of the magma.

Many glomeroporphyritic aggregates of plagioclase are joined in a synneusis relationship, which indicates crystallization in a magma chamber (Vance, 1969). Other aggregates are clustered in a random fashion. Some of these aggregate crystals have broad rims that are also oscillatory zoned, suggesting origin by slower cooling (Bottinga et al., 1966).

Phenocrysts commonly have overgrowth rims that are more sodic than the cores (Tables 2, 3 and Figs. 4, $5)$. The boundaries between core and rim overgrowths are usually noted by a discontinuity corresponding to a compositional gap or gradient (Figs. 4, 5). Lofgren (1974) has duplicated concentrically zoned plagioclase in the laboratory by successive rapid drops in temperature. Each zone becomes progressively albite-rich outwards from the core and has a marked discontinuity with neighboring zones. The discontinuities are correlated with a period of rapid temperature drop, but each zone corresponds to a growth period under new temperature conditions. Translating these to the crystallization history of the basalts, we can correlate each discontinuity between zones to a period of rapid ascent of the magma and each zone to a period when the magma was pooled into a magma chamber at a certain depth and underwent some crystallization. Thus, rim compo- 

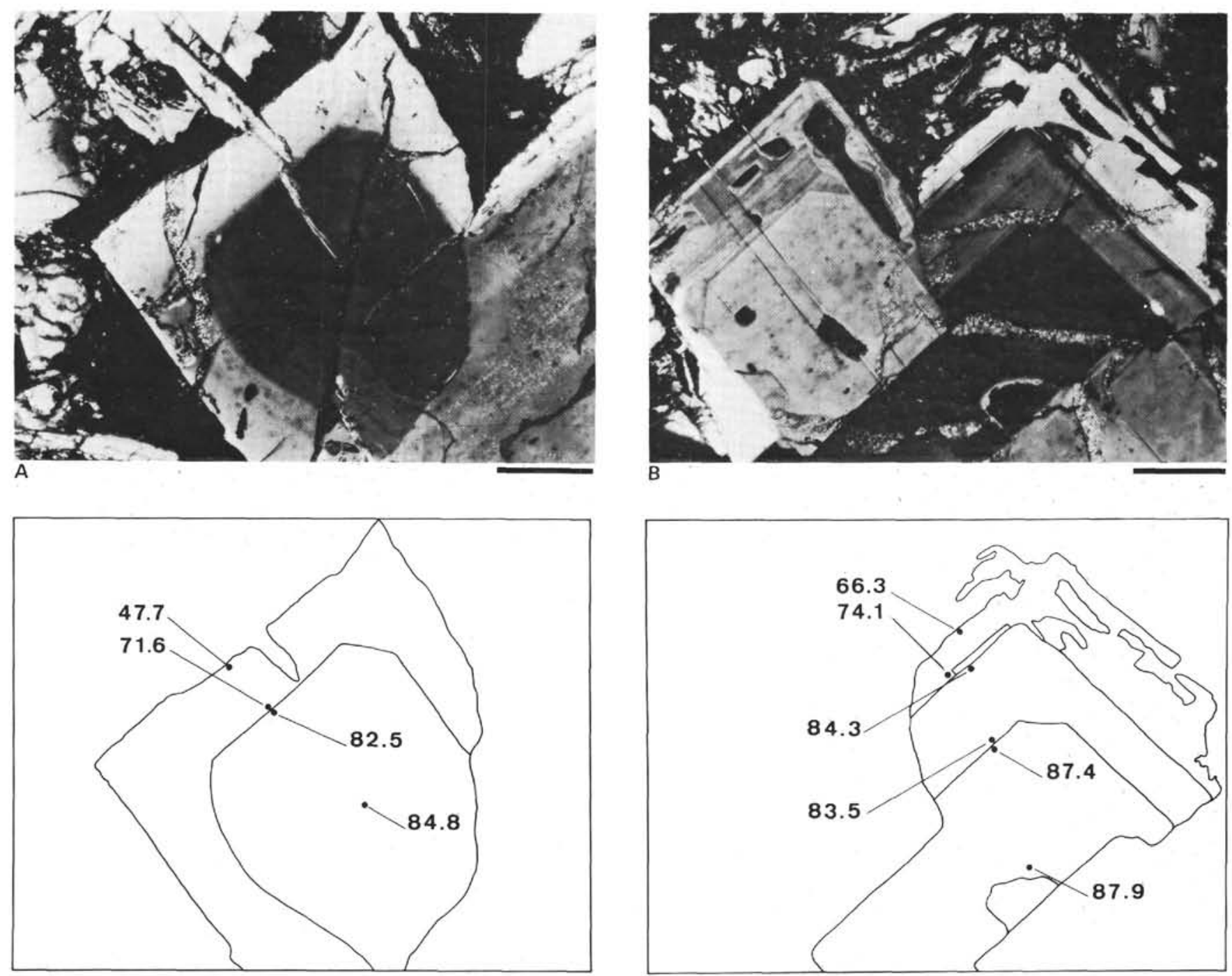

Figure 5. Plagioclases with overgrowth rims having compositional discontinuities. A. Second generation microphenocryst from $483 \mathrm{~B}-2-7,91 \mathrm{~cm}$. (Scale bar equals $0.1 \mathrm{~mm}$.) B. Glomerocryst from 483B-13-3, $129 \mathrm{~cm}$. (Scale bar equals $0.1 \mathrm{~mm}$.)

sitions in conjunction with phenocryst and microphenocryst compositions can be used to map the crystallization history of the magma.

The compositions and morphologies of the plagioclase suggest four phases of crystallization in most of the basalts. Phase 1 is represented by phenocrysts with core compositions of about $\mathrm{An}_{92-85}$. These crystals have large equant morphologies which show slight embayments, cores with glass inclusions, multiple overgrowth rims with more sodic compositions, and, in one phenocryst, a chromium spinel inclusion $\left(\mathrm{Mg}_{0.69}, \mathrm{Fe}_{0.39}\right.$, $\left.\mathrm{Cr}_{0.71}, \mathrm{Al}_{1.18}, \mathrm{O}_{4}\right)$. Anorthite and spinel compositions match those found in mafic cumulates thought to represent Oceanic Layer 3 (Hodges and Papike, 1976). Thus, we suggest they may be xenocrysts either from Oceanic Layer 3 or from a feldspathic peridotite from the mantle. However, it is just as likely that these formed by crystallization at depth. The phenocrysts in Phase 2 have core compositions of $\mathrm{An}_{85-78}$, tend to be more equant than tabular, and have overgrowth rims. Equant morphologies suggest that these phenocrysts had a deeper source than those of Phase 3, which is noted by phenocrysts with core compositions of about $\mathrm{An}_{74-65}$. These crystals are more tabular than equant and commonly have trapped melt inclusions. Crystallization of these phenocrysts was probably from a shallow magma chamber. Phase 4 is represented by phenocrysts, microphenocrysts, and groundmass formed upon eruption. The anorthite contents in these crystals have a range of about $\mathrm{An}_{74-35}$. The crystals characteristically show features of rapid cooling, such as trapped melt inclusions and skeletal to acicular shapes. The plagioclase crystals associated with Phase 4 are commonly in a "bow tie" intergrowth with pyroxenes, which we have interpreted as having grown as quench phases during eruption.

\section{Glass Analyses}

Glass analyses and accompanying CIPW norms are listed in Table 4 . These are quite similar to other oceanic 
Table 2. Selected microprobe analyses of plagioclase phenocrysts from Hole 483.

\begin{tabular}{|c|c|c|c|c|c|c|c|c|c|c|c|c|c|c|c|c|c|c|c|c|c|c|c|c|c|c|}
\hline & la & $\mathrm{Ib}$ & Ic & Id & le & If & $2 a$ & $2 b$ & $2 c$ & $2 \mathrm{~d}$ & $3 a$ & $3 \mathrm{~b}$ & $3 c$ & $3 d$ & $4 a$ & $4 \mathrm{~b}$ & $4 c$ & $4 d$ & $5 \mathrm{a}$ & $5 b$ & $6 a$ & $6 \mathrm{~b}$ & $7 a$ & $7 \mathrm{~b}$ & $7 \mathrm{c}$ & $7 d$ \\
\hline $\mathrm{si}$, & 45.0 & 46.4 & 47.9 & 47.2 & 49.3 & 51.3 & 48.6 & 48.4 & 51.3 & 51.5 & 45.4 & 46.8 & 48.6 & 51.1 & 48.2 & 49.0 & 51.9 & 51.3 & 47.1 & 47.8 & 51.0 & 53.0 & 47.9 & 48.2 & 49.7 & 49.5 \\
\hline & 34.4 & 36.6 & 33.1 & 33 & 32 & 30.4 & 32.1 & 33.0 & 31.2 & 29.8 & 34.2 & 33.3 & 32.8 & 31.4 & 33.1 & 32.7 & 29.9 & 31.0 & 33.2 & 33.1 & 31.1 & 29.8 & 32.6 & 32.4 & 31.5 & 31.6 \\
\hline 0 & 0.4 & 0.4 & 0 & & & 0 & & 0.5 & 0.6 & 0.7 & 0.5 & 0.5 & 0.5 & 0.7 & 0.5 & 0.5 & 0.7 & 0.7 & 0.5 & & & & & & & 0.7 \\
\hline Mgg & 0.2 & 0.1 & 0.2 & 0 & 0 & 0.1 & 0.2 & 0.2 & & 0.2 & 0.0 & 0.1 & 0 . & 0.2 & 0.1 & 0.1 & 0.2 & 0.2 & 0.2 & 0.2 & 0.1 & 0.2 & 0.2 & 0.2 & 0.2 & 0.2 \\
\hline $\mathrm{CaO}$ & 18.3 & 18.4 & 16.8 & 17.0 & 15.3 & 13.8 & 16.6 & 16.6 & 5.0 & 14.4 & 18.1 & 17.3 & 16.5 & 14.3 & 16.9 & 16.5 & 14.1 & 14.7 & 16.9 & 16.5 & 14.5 & 13.3 & 16.1 & 16.1 & 14.6 & 15.1 \\
\hline & 1.3 & & 1. & & 2.9 & & & & & 3.2 & 1.1 & 1 & 2. & 3. & 1.9 & 2. & 3.2 & 3.1 & 1.5 & 2.0 & 3.1 & & 2.4 & 1.9 & 2.8 & 2.7 \\
\hline $\mathrm{K}_{2} \mathrm{O}$ & 0.0 & 0.0 & 0.1 & 0.0 & 0.1 & 0.1 & 0.0 & 0.0 & 0.0 & 0.0 & 0.0 & 0.0 & 0.0 & 0.0 & 0.0 & 0.0 & 0.0 & 0.0 & 0.0 & 0.0 & 0.0 & 0.0 & 0.0 & 0.0 & 0.0 & 0.0 \\
\hline Total & 99.6 & 101.1 & 100.4 & 100.1 & 100.4 & 100.1 & 100.0 & 100.8 & 101.3 & 99.8 & 99.3 & 99.5 & 100.5 & 100.9 & 100.7 & 100.8 & 100.0 & 101.0 & 99.4 & 100.1 & 100.4 & 100.8 & 99.7 & 99.4 & 99.4 & 99.8 \\
\hline Or & - & - & 0. & - & 0 . & & - & - & - & - & - & - & - & - & & & & & & & & & & & & \\
\hline An & 88.8 & & & & & & & & & 71.5 & 90.5 & 86.4 & 81. & 71. & & & & & & & & & & & & 75.6 \\
\hline $\mathrm{Ab}$ & 11.2 & 10.4 & 16.0 & 17.1 & 25.5 & 32.2 & 17.8 & 18.7 & 26.7 & 28.5 & 9.5 & 13.6 & 18.7 & 28.6 & 16.7 & 18.3 & 29.4 & 27.7 & 17.4 & 17.8 & 28.1 & 34.3 & 21.0 & 17.6 & 25.5 & 24.4 \\
\hline
\end{tabular}

Note: 1a-1b core to innermost rim in embayed equant megacryst with spinel inclusion; 1c-1d intermediate rim; le-1f outer rim, 483-13-4, $64 \mathrm{~cm}$.

$2 \mathrm{a}-2 \mathrm{~b}$ core to rim of phenocryst with rounded core and melt inclusions; $2 \mathrm{c}-2 \mathrm{~d}$ surrounding rim, $483-20-1,49 \mathrm{~cm}$.

$3 \mathrm{a}-3 \mathrm{~b}$ core to rim in phenocryst with euhedral equant core; $3 \mathrm{c}-3 \mathrm{~d}$ surrounding rim, $483-22-1,2 \mathrm{~cm}$.

$4 \mathrm{a}-4 \mathrm{~b}$ core to rim in euhedral phenocryst; $4 \mathrm{c}-4 \mathrm{~d}$ surrounding rim, $483-22-1,2 \mathrm{~cm}$.

作

in subhedral equant phenocryst; 7c-7d surrounding rim, 483-26-3, $146 \mathrm{~cm}$

Table 3. Selected microprobe analyses of plagioclase phenocrysts from Hole 483B.

\begin{tabular}{|c|c|c|c|c|c|c|c|c|c|c|c|c|c|c|c|c|c|c|c|c|c|c|c|c|c|c|}
\hline & la & tb & Ic & $1 d$ & le & If & $2 a$ & $2 b$ & $2 c$ & $2 \mathrm{~d}$ & $2 e$ & $2 \mathrm{f}$ & $2 g$ & $2 \mathrm{~h}$ & $3 a$ & $3 b$ & $4 a$ & $4 \mathrm{~b}$ & $5 \mathrm{a}$ & $5 b$ & $5 c$ & $5 \mathrm{~d}$ & $6 a$ & $6 \mathrm{~b}$ & $6 c$ & $6 \mathrm{~d}$ \\
\hline & 47.3 & 45.9 & 50.2 & 47.6 & 51.6 & 54.1 & 46.6 & 46.9 & 48.7 & 48.3 & 48.9 & 57.4 & 50.2 & 60.7 & 49.3 & 49.4 & 49.5 & 52.4 & 48.0 & 48.5 & 50.5 & 52.0 & 47.3 & 47.4 & 51.2 & 51.6 \\
\hline & & & & & & & & & & 32. & & & & & & & & & 32.6 & & & & & & & 30.9 \\
\hline & 0.1 & 0.1 & 0.1 & 0.1 & 0.1 & 0.2 & 0.5 & 0.6 & 0.5 & 0.6 & 0.5 & 1.0 & 0.5 & 2.5 & 0.6 & 0.5 & 0.6 & 0.7 & 0.5 & 0.5 & 0.5 & 0.6 & 0.4 & 0.4 & 0.6 & 0.7 \\
\hline$g$ & 0 & 0.1 & & 0 & 0.2 & 0. & 0.1 & 0 & 0 & 0 & 0 & & 0 & & 0 & 0 & & & & & & & & & & 0.2 \\
\hline & 18.3 & 18.2 & 15.6 & 16.4 & 13.8 & 12.3 & 17.8 & 17.0 & 15.8 & 16.5 & 15.2 & & 15.2 & & 15 & 16.1 & 14.8 & 13. & 16.7 & 16 & 14 & 13 & & & & 14.7 \\
\hline $\mathrm{Na}_{2}$ & 1.0 & 0.9 & 2.4 & 1.8 & 0.29 & 3.7 & 1.5 & 1.7 & 2.2 & 2.0 & 2.9 & 5. & 2.7 & 4.4 & 2.2 & 1.7 & 2.8 & 3. & 1.8 & 2 & 3 & 3. & 1.6 & 1.6 & 3.3 & 3.1 \\
\hline $\mathrm{K}_{2}$ & - & - & - & - & - & - & - & - & - & - & - & 0.6 & - & 1.3 & & - & - & & 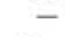 & 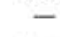 & 0.1 & - & - & - & 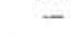 & - \\
\hline Total & 01.2 & 99.9 & 100.5 & 98.4 & 98.4 & 98.5 & 99.7 & 98.8 & 99.0 & 99.6 & 98.4 & 100.3 & 99.6 & 100.9 & 100.6 & 99.7 & 99.6 & 100.0 & 99.7 & 99.6 & 99.7 & 100.4 & 100.0 & 100.2 & 100.5 & 101.2 \\
\hline Or & - & - & - & - & - & - & - & - & - & - & - & & - & & & - & - & - & - & - & & - & - & - & - & \\
\hline $\mathrm{Ar}$ & 91.0 & 91.8 & 78.4 & 83.2 & 72.3 & 64.5 & 86.9 & & 79.5 & 82.3 & 74.2 & & 75 & & 80 & 83.6 & 7. & 6 & 83.8 & & & & & & & 72.1 \\
\hline $\mathrm{Ab}$ & 8.9 & 8.1 & 21.5 & 16.6 & 27.4 & 35.2 & 13.0 & 15.4 & 20.4 & 17.6 & 25.6 & 50.1 & 24.3 & 49.2 & 19.8 & 16.2 & 25.7 & 33.6 & 16.0 & 19.5 & 26.9 & 31.3 & 14.4 & 14.3 & 29.2 & 27.7 \\
\hline
\end{tabular}

Note: la-1b core to rim in phenocryst with euhedral equant core; $1 \mathrm{c}-1 \mathrm{~d}$ core to rim in euhedral equant core; le-1f core to rim in phenocryst, $483 \mathrm{~B}-2-1,91 \mathrm{~cm}$. $2 \mathrm{a}-2 \mathrm{~b}$ core to innermost rim of phenocryst core; $2 \mathrm{c}-2 \mathrm{~d}$ intermediate rim; $2 \mathrm{e}-2 \mathrm{f}$ outer rim; $2 \mathrm{~g}-2 \mathrm{~h}$ tabular phenocryst, $483 \mathrm{~B}-13-3,129 \mathrm{~cm}$.

$3 \mathrm{a}-3 \mathrm{~b}$ core to innermost rim of phenocryst with numerous melt inclusions, 483B-19-1, $109 \mathrm{~cm}$.

$4 a-4 b$ core to rim of tabular-phenocryst in "bow tie" glomerocryst; 483B-22-1, $51 \mathrm{~cm}$.

$6 \mathrm{a}-6 \mathrm{~b}$ core to innermost rim of equant phenocryst; $6 \mathrm{c}-6 \mathrm{~d}$ surrounding rim, $483 \mathrm{~B}-30-1,140 \mathrm{~cm}$. 
Table 4. Glass analyses with CIPW norms.

\begin{tabular}{|c|c|c|c|c|c|}
\hline & \multicolumn{5}{|c|}{ Sample } \\
\hline & $\begin{array}{c}489-20-1 \\
49 \mathrm{~cm}\end{array}$ & $\begin{array}{c}483-22-1 \\
2 \mathrm{~cm}\end{array}$ & $\begin{array}{c}483 \mathrm{~B}-22-1 \\
51 \mathrm{~cm}\end{array}$ & $\begin{array}{c}483 \mathrm{~B}-20-1 \\
140 \mathrm{~cm}\end{array}$ & $\begin{array}{c}483 \mathrm{~B}-32-2, \\
141 \mathrm{~cm}\end{array}$ \\
\hline $\mathrm{SiO}_{2}$ & 50.3 & 50.5 & 51.4 & 49.4 & 51.0 \\
\hline $\mathrm{TiO}_{2}$ & 1.6 & 1.6 & 1.6 & 1.9 & 1.3 \\
\hline $\mathrm{Al}_{2} \mathrm{O}_{3}$ & 15.0 & 14.6 & 14.4 & 14.8 & 15.6 \\
\hline $\mathrm{FeO}$ & 9.4 & 8.9 & 9.4 & 9.7 & 7.3 \\
\hline $\mathrm{MnO}$ & 0.2 & 0.2 & 0.2 & 0.3 & 0.1 \\
\hline $\mathrm{MgO}$ & 7.6 & 8.2 & 8.0 & 7.7 & 8.1 \\
\hline $\mathrm{CaO}$ & 12.6 & 12.8 & 12.8 & 12.4 & 13.2 \\
\hline $\mathrm{Na}_{2} \mathrm{O}$ & 2.5 & 2.4 & 2.5 & 2.5 & 2.5 \\
\hline $\mathrm{K}_{2} \mathrm{O}$ & 0.1 & 0.1 & 0.1 & 0.1 & 0.1 \\
\hline $\mathrm{P}_{2} \mathrm{O}_{5}$ & 0.2 & 0.2 & 0.2 & 0.2 & 0.1 \\
\hline Total & 99.5 & 99.5 & 100.6 & 99.0 & 99.3 \\
\hline \multicolumn{6}{|c|}{ C.I.P.W. Norm } \\
\hline Q & - & - & - & - & - \\
\hline An & 29.4 & 28.7 & 27.7 & 28.8 & 31.0 \\
\hline $\mathrm{Ab}$ & 21.1 & 20.3 & 21.1 & 21.1 & 21.1 \\
\hline Or & 0.6 & 0.6 & 0.6 & 0.6 & 0.6 \\
\hline Di & 26.2 & 27.3 & 28.2 & 25.8 & 27.4 \\
\hline Wo & 13.3 & 14,0 & 14.4 & 13.1 & 14.1 \\
\hline En & 7.2 & 7.9 & 7.9 & 7.1 & 8.5 \\
\hline Fs & 5.7 & 5.4 & 5.9 & 5.6 & 4.8 \\
\hline Hy & 12.3 & 13.3 & 14.7 & 9.9 & 11.3 \\
\hline En & 6.9 & 7.9 & 8.4 & 5.5 & 7.2 \\
\hline Fs & 5.4 & 5.4 & 6.3 & 4.4 & 4.1 \\
\hline $\mathrm{Ol}$ & 6.5 & 5.8 & 4.7 & 8.8 & 5.2 \\
\hline Fo & 3.5 & 3.3 & 2.6 & 4.7 & 3.2 \\
\hline $\mathrm{Fa}$ & 3.0 & 2.5 & 2.1 & 4.1 & 2.0 \\
\hline Il & 3.0 & 3.0 & 3.0 & 3.6 & 2.5 \\
\hline Ap & 0.4 & 0.4 & 0.4 & 0.4 & 0.2 \\
\hline
\end{tabular}

glasses (Melson et al., 1976) and are typically hypersthene-olivine normative.

\section{CONCLUSIONS}

Based on textural and compositional data, we suggest that the basalts from Site 483 show a multistage cooling history involving possible contamination. At depth, the basaltic magma either crystallized or was contaminated with a very $\mathrm{An}$-rich plagioclase $\left(\mathrm{An}_{92-85}\right)$ and chromian spinel, possibly from a feldspathic peridotite from the oceanic mantle. Subsequently in a shallower chamber, a slightly more $\mathrm{Ab}$-rich plagioclase $\left(\mathrm{An}_{85-78}\right)$ may have crystallized with olivine from the melt. The plagioclase zonation indicates possible crystallization in a very shallow (crustal?) tertiary magma chamber prior to eruption. Plagioclase with a composition of $\mathrm{An}_{74-65}$ may have crystallized during this period. Finally, quench phases of olivine, clinopyroxene, and plagioclase nucleated and grew during eruption and final emplacement.

\section{ACKNOWLEDGMENTS}

We gratefully acknowledge M. A. Morrison and R. V. Fodor for their helpful, critical reviews. This study was supported in part by a UNM Research Allocations grant to A. M. Kudo, and by National Aeronautics and Space Administration grants (NGL 32-004-063 and 32-004-064) to K. Keil.

\section{REFERENCES}

Bence, A. E., and Albee, A. L., 1968. Empirical correction factors for the electron microanalysis of silicates and oxides. J. Geol., 76: 382-403.

Bence, A. E., Papike, J. J., and Ayuso, R. A., 1976. Petrology of submarine basalts from the central Caribbean: DSDP Leg 15. J. Geophys. Res., 80:4775.

Blackerby, B. A., 1968. Convolute zoning of plagioclase phenocrysts in Miocene volcanics from the western Santa Monica Mountains, California. Am. Mineral., 53:954-962.

Blanchard, D. P., Rhodes, J. M., Dungan, M. A., et al., 1976. The chemistry and petrology of basalts from Leg 37 of the Deep Sea Drilling Project. J. Geophys. Res., 81:4231-4246.

Bottinga, Y., Kudo, A., and Weill, D., 1966. Some observations on oscillatory zoning and crystallization of magmatic plagioclase. Am. Mineral., 51:792-806.

Bryan, W. B., 1972. Morphology of quench crystals in submarine basalts. J. Geophys. Res., 77:5812-5819.

Bryan, W. B., Thompson, G., Frey, F. A., et al., 1976. Inferred settings and differentiation in basalts from the Deep Sea Drilling Project. J. Geophys. Res., 81:4285-4304.

Bunch, T. E., and LaBorde, R., 1976. Mineralogy and compositions of selected basalts from DSDP Leg 34. In Yeats, R. S., Hart, S. R., et al., Init. Repts. DSDP, 34: Washington (U.S. Govt. Printing Office), 263-275.

Coish, R. A., and Taylor, L. A., 1979. The effect of cooling rate on texture and pyroxene chemistry in DSDP Leg 34 basalt: A microprobe study. Earth Planet. Sci. Lett., 42:389-398.

Donaldson, C. H., and Brown, R. W., 1977. Refractory megacrysts and magnesium-rich melt inclusions within spinel in oceanic tholeiites: Indicators of magma mixing and parental magma composition. Earth Planet. Sci. Lett., 29:7-20.

Hodges, F. N., and Papike, J. J., 1976. DSDP Site 334: Magmatic cumulates from oceanic layer 3. J. Geophys. Res., 81:4135-4151.

Hollister, L. S., and Hargraves, R. B., 1970. Compositional zoning and its significance in pyroxene from two coarse-grained Apollo 11 samples. Proc. Apollo 11 Lunar Sci. Conf., 1:541-550.

Hollister, L. S., Trzcienski, W. E., Jr., Hargraves, R. B., et al., 1971. Petrogenetic significance of pyroxenes in two Apollo 12 samples. Proc. Second Lunar Sci. Conf., 1:529-557.

1972. Crystallization histories of two Apollo 12 basalts. Mem. Geol. Soc. Am. 132:641-650.

Kirkpatrick, R. J., 1976. Towards a kinetic model for crystallization of magma bodies. J. Geophys. Res., 81:25-65.

Lofgren, G. E., 1973. Temperature induced zoning in synthetic plagioclase feldspars. Proc. NATO Conf. Feldspars: Manchester (Manchester Press).

1974. An experimental study of plagioclase morphology: Isothermal crystallization. Am. J. Sci., 274:243-273.

Lofgren, G. E., and Smith, D. P., 1980. The experimental determination of cooling rates of rocks: Some complications. Eleventh Lunar Planet. Sci. Conf., pp. 631-633. (Abstract)

Melson, W. G., Byerly, G. R., Nelen, J. A., et al., 1976. A catalog of the major element chemistry of abyssal volcanic glasses. Smithson. Contrib. Earth Sci., 19:31-60.

Natland, J. H., 1979. Crystal morphologies in basalts from DSDP Site $395,23^{\circ} \mathrm{N}, 46^{\circ} \mathrm{W}$, Mid-Atlantic Ridge. In Melson, W. G., Rabinowitz, P. D., et al., Init. Repts. DSDP, 45: Washington (U.S. Govt. Printing Office), 423-445.

Sato, H., 1977. Nickel content of basaltic magmas: Identification of primary magmas and a measure of the degree of olivine fractionation. Lithos, 10:113-120.

Thompson, G., Bryan, W. B., Frey, F. A., et al., 1976. Petrology and geochemistry of basalts from DSDP Leg 34, Nazca Plate. In Yeats, R. S., Hart, S. R., et al., Init. Repts. DSDP, 34: Washington (U.S. Govt. Printing Office), 215-226.

Vance, J. A., 1969. On synneusis. Contrib. Mineral. Petrol., 24:7-29. 

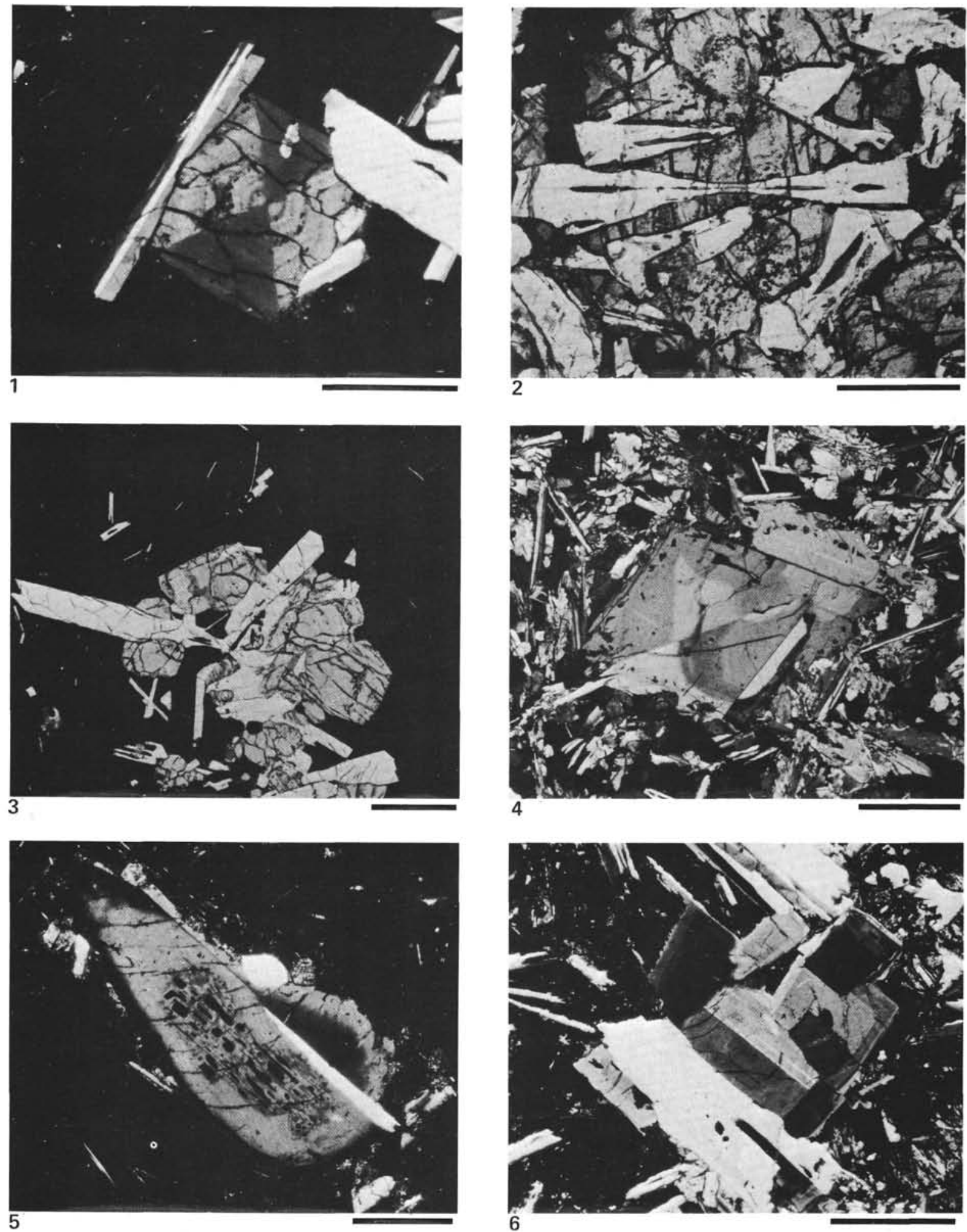

Plate 1. Photomicrographs of various textural relationships in rocks from Holes 483 and 483B. 1. Sector-zoned pyroxene with superimposed oscillatory zoning (483B-22-1, $51 \mathrm{~cm}$ ). (Scale bar equals $0.5 \mathrm{~mm}$.) 2. "Bow tie" relationship between plagioclase and clinopyroxene in groundmass (483B-28-1, $78 \mathrm{~cm}$ ). (Scale bar equals $0.5 \mathrm{~mm}$.) 3. Glomerocrysts with "bow tie" intergrowth of plagioclase and clinopyroxene (483B22-1, $51 \mathrm{~cm}$ ). (Scale bar equals $1.0 \mathrm{~mm}$.) 4. Plagioclase phenocrysts showing sector zoning $(483-23-1,132 \mathrm{~cm})$. (Scale bar equals $0.5 \mathrm{~mm}$.) 5. Plagioclase phenocrysts with trapped melt inclusions. Note the convolute zoning around the inclusions $(483-20-1,49 \mathrm{~cm})$. (Scale bar equals $0.5 \mathrm{~mm}$.) 6. Glomerocrysts of plagioclase showing synneusis relationship (483B-13-3, $129 \mathrm{~cm})$. (Scale bar equals $0.5 \mathrm{~mm}$.) 